\title{
PRE-SERVICE TEACHERS' COGNITIVE CONSTRUCTS REGARDING THE CHARACTERISTICS OF A GOOD INFORMATION TECHNOLOGIES ACADEMICIANS
}

\section{Mehmet Ramazanoğlu}

Siirt University, Turkey

Doi:10.19044/ejes.v8no1a1

URL:http://dx.doi.org/10.19044/ejes.v8no1a1

$\begin{array}{ll}\text { Submitted: } 07 \text { December } 2020 & \text { Copyright 2021 Author(s) } \\ \text { Accepted: } 08 \text { March 2021 } & \text { Under Creative Commons BY- } \\ \text { Published: } 31 \text { March 2021 } & \text { NC-ND 4.0 OPEN ACCESS }\end{array}$

\section{Abstract}

This paper focuses on revealing and modeling the cognitive constructs of pre-service teachers regarding the characteristics of a good IT academician. The research was carried out via the exploratory sequential design with the participation of 42 volunteer pre-service teachers enrolled in the Department of Computer and Instructional Technology. The data were obtained through the structured interview according to the repertory grid technique. The data obtained were analysed by taking into consideration similarities and common features. 426 cognitive constructs were found. Cognitive constructs were collected under 11 sub-categories. These categories were also divided into three main categories: attitudes and values, professional knowledge, and professional skills. As a result, essential constructs within the model of a good academician include the relationship among students, knowledge of field education, and field knowledge. The model revealed a whole set of characteristics rather than a few characteristics of a good IT academician. The model can be used to evaluate IT academicians and to explain the relationship among their characteristics.

Keywords: Pre-Service Teachers', Good IT academician, Cognitive constructs, IT academician Characteristics

\section{Introduction}

Education is a process that helps individuals gain knowledge, skills, and insights required for self-realization in society and teaching effectiveness. Basically, there are two indispensable factors in education. These are those who teach (teacher) and who learn (student) (Akgün, 2016), followed by physical fitness and some other factors. A teacher refers to a person specialized in both practical and theoretical fields, who uses different 
teaching and learning environments in the most effective way and constantly interacts with students (Başaran, 1993). A teacher is traditionally seen as the person who obtains and transfers information. However, advancing technology has changed the way students have access to information. Although such advances make access to information simpler, students need mentors to guide them (Karacaoğlu, 2008). Technological advances have significant influences on the educational, socio-cultural, socio-economic, and political structures of the countries.

Consequently, technology is used in various forms of education depending on the field. One of these fields is the field of information technologies. Information technologies (IT) is a system that uses communication technologies with the computer and transforms data into information (Özdemir \& Pınar, 2019). IT is conceived as data that can be meaningful and useful for users (Akolaş, 2009). Information technologies ensure that we complete tasks more quickly as well as increase the effectiveness and quality of tasks. The demand for information technologies is increasing day by day and if such demand emerges at a young age, then the use of technology may be more accurate and effective (Özgenel, Baydar \& Çalışkan Yılmaz, 2018). Being more common today, information technologies have started to play a role, particularly in education, by imposing several obligations on educators and requiring several characteristics that good and ideal teachers should possess apart from professional development.

Some studies have been conducted on the characteristics of good teachers. According to Kivinen and Rinne (1995), a good teacher should be a success-oriented and healthy one who has the ability to undertake the responsibility of management and produce creative ideas. Witcher and Onwuegbuzie (1999), on the other hand, stated that pre-service teachers were of the opinion that a good teacher should be student-centred. In the study based on student opinions to determine the competencies of teachers, Senemoglu (2001) reached the following conclusions: A good teacher should make necessary preparations before the lesson starts, be solution-oriented and aware of how students best learn, maintain discipline in the classroom, strive to strengthen students' motivation, use the necessary materials, and always show love and respect. In another study, it was determined that a good teacher should be mainly student-centred (Minor, Onwuegbuzie, Witcher \& James, 2002). In another study, some of the characteristics of a good teacher include motivating and guiding students, helping them gain self-confidence, establishing good relationships, and commanding respect for one another (Telli, Brok, \& Cagiroglu, 2008). In his study related to the teacher of English, Khan (2011) claims that teachers, in general, should be role models to future generations by being good instructors, facilitators, and curriculum developers. In another study with 224 pre-service teachers, four main characteristics of a good teacher were given as respect, responsibility, reliability, and honesty (Gallavan, Peace \& Thomason, 2009). Ulusoy (2013) conducted a study with 234 elementary pre-service teachers attending a public university in Ankara with the conclusion that a good classroom 
teacher should possess a love for children and his or her profession. Başaran and Baysal (2016) also revealed that pre-service teachers believe that a good teacher should not only impart knowledge but also keep teaching interestingly. Also, pre-service teachers should have a good knowledge of the field and a love for the profession, and moral values. Sezer (2018) studied the cognitive structure of 21 pre-service teachers and found 210 cognitive structures in eight categories emerged. The frequently repeated cognitive structures in the research were "communication skills, professional competence, field expertise, motivational skills, friendliness, fair behavior, respect for opinions, creativity, innovation, academic equipment, being scientific and classroom management".

Personal constructs are used in the researches based on the opinions of individuals. Many theories in the literature explain the personal construct. In this research, the personal construct theory developed by Kelly (1955) was taken as a basis. This theory does not take into account the common perceptions of individuals in the group; on the contrary, it gathers data based on individual perceptions (Kelly, 1991). Personal structure theory aims to explain that individuals' tendencies in their psychological systems are formed through their experiences as each individual has distinctive experiences. Each individual is expected to make more valid and realistic predictions about real-life events (Adams-Webber, 1996). The basic foundation of the personal construct is the cognitive construct. The cognitive construct determines the general lines in which a range of information is combined and how this range of information should be related (Cüceloğlu, 1991). This construct plays a crucial role in remembering and learning. The cognitive construct is defined as new interconnected information as interconnected groups used to separate them (Davidson, 1977). Kelly (2003), on the other hand, stated that they use various fictional constructs to express the dimensions of the individuals' experiences, which are based on the sentences and definitions that individuals express.

Moreover, it has been observed that the characteristics of a good teacher and academician are revealed in different fields based on these analyses. However, there is no consensus on the characteristics that good academicians should possess and no study that reveals these characteristics. In this context, it is important to determine the cognitive constructs regarding the characteristics of the senior IT pre-service teachers. It is believed that if the characteristics of a good academician are revealed, then IT academicians may be better evaluated based on these characteristics. Therefore, this study aimed to reveal and model the characteristics of a good IT academician in the cognitive constructs of pre-service IT teachers. For this purpose, the following research questions were addressed:

1. What are the first ten cognitive constructs of pre-service IT teachers regarding the characteristics of a good IT academician?

2. What are the sub-categories of cognitive constructs of pre-service IT teachers regarding the characteristics of a good IT academician?

3. To what extent are these sub-categories important?

4. What are the main categories of these sub-categories? 
5. How do pre-service IT teachers model a good IT academician in their cognitive constructs?

\section{Method}

This section includes the design, participants, data collection tool, and data analysis of the research.

\section{Research Design}

This research is based on the exploratory sequential design as one of the mixed model methods. The mixed model ensures that both qualitative and quantitative data are obtained and it unearths results by combining two sets of these data (Creswell, 2003). Within the exploratory sequential design, on the other hand, the researcher collects and analyzes the qualitative data from the study group at the first stage, while the researcher collects quantitative data and tests or generalizes these data (relationship and similarity) at the second stage (Creswell, 2003).

\section{Participants}

Participants were 42 volunteer pre-service teachers attending the fourth-grade education of computer and instructional technology education departments of three public universities in the spring term of the 2019-2020 academic year. The research was limited to the fourth-grade pre-service teachers as they were thought to reveal distinctive characteristics. The demographic characteristics of pre-service teachers were presented in Table1.

\section{Table 1. The Demographic Characteristics of Pre-Service Teachers}

\begin{tabular}{lcll}
\hline Universities & Gender & $\mathrm{N}$ & $\%$ \\
\hline University & $\mathrm{F}$ & 9 & 21 \\
& $\mathrm{M}$ & 11 & 26 \\
University & $\mathrm{F}$ & 7 & 17 \\
University & $\mathrm{M}$ & 5 & 12 \\
& $\mathrm{~F}$ & 6 & 14 \\
& $\mathrm{M}$ & 4 & 10 \\
\hline
\end{tabular}

\section{Data Collection Tool}

Data were obtained through an interview form structured based on the repertory grid technique. The repertory grid is a technique that was developed to identify the ways that a person construes his or her experience (Kelly, 1955). The researcher asked participants to write down at least 10 characteristics that may identify three good IT academicians. The data obtained were used to identify the cognitive constructs of pre-service IT teachers. It was decided by the ethics committee unit of Siirt University that there are no objections in terms of research ethics in the research in accordance with the decision dated 2020 and numbered 1816 . 


\section{Data Analysis}

426 positive cognitive structures emerged via the repertory grid form applied to pre-service IT teachers. Before starting the analysis, the first 10 cognitive constructs were identified and then these constructs were analyzed by taking into consideration similarities and common features. After the analysis, cognitive constructs were first ranked in sub-categories and then in main categories. Accordingly, the characteristics of good academicians were divided into 11 sub-categories and 3 main categories. The categories were grouped in such a way that no cognitive construct was excluded. In order to add relative values to the cognitive constructs reached in such studies, the hypothesis "first answers precede those reached later" (Gordon, 1968). Accordingly, the first cognitive construct of pre-service teachers participating in the study was graded as 10 while the other cognitive constructs were graded backward, respectively. In the research, the cognitive constructs of the pre-service teachers were ranked according to frequency and averages. It was observed that some of the pre-service IT teachers mentioned negative constructs of the characteristics of IT academicians in the relevant repertory grid form. Since this situation does not match the purpose of the research, 9 repertory grid forms were not included in the analysis.

\section{Findings}

426 positive cognitive constructs emerged as shown in Table 2, which includes the first 10 cognitive constructs.

\section{Table 2. The First Ten Cognitive Constructs}

\begin{tabular}{lll}
\hline Cognitive Constructs & $\mathrm{N}$ & $\%$ \\
\hline Student-centeredness & 28 & 6,57 \\
Good command of technology & 25 & 5,87 \\
Field knowledge & 24 & 5,63 \\
Good command of a specific course & 19 & 4,46 \\
Good Communication & 19 & 4,46 \\
Openness to innovation & 19 & 4,46 \\
Loving job & 14 & 3,29 \\
Guidance & 11 & 2,58 \\
Learning to teach & 10 & 2,35 \\
Classroom management & 10 & 2,35 \\
\hline
\end{tabular}

Table 2 shows that the first ten cognitive constructs of pre-service IT teachers regarding the characteristics of good IT academicians are studentcenteredness $(\mathrm{N}=28,6.57 \%)$, good command of technology $(\mathrm{N}=25,5.87 \%)$, field knowledge $(\mathrm{N}=24,5.63 \%)$, good command of a specific course $(\mathrm{N}=19$, $4.46 \%)$, good communication ( $\mathrm{N}=19,4.46 \%)$, openness to innovation $(\mathrm{N}=19$, $4.46 \%)$, loving for job $(\mathrm{N}=14,3.29 \%)$, guidance $(\mathrm{N}=11,2.58 \%)$, learning to 
teach $(\mathrm{N}=10,2.35 \%)$ and classroom management $(\mathrm{N}=10,2.35 \%)$, respectively. Thus, these cognitive constructs were divided into sub-categories as shown in Table 3.

\section{Table 3. Sub-Categories of the Cognitive Constructs}

\begin{tabular}{lll}
\hline \multicolumn{1}{c}{ Sub-categories } & $\mathrm{N}$ & $\%$ \\
\hline The relationship with students & 106 & 24,88 \\
Knowledge of field education & 61 & 14,32 \\
Communication and cooperation & 56 & 13,15 \\
Field knowledge & 55 & 12,91 \\
Management of the teaching and learning process & 38 & 8,92 \\
Personal and Professional Development & 34 & 7,98 \\
Creating Learning Environments & 23 & 5,40 \\
Universal values & 22 & 5,16 \\
Education Planning & 21 & 4,93 \\
Knowledge of Regulations & 8 & 1,88 \\
Assessment and Evaluation & 2 & 0,47 \\
\hline
\end{tabular}

Table 3 shows 11 sub-categories which includes the relationship with students ( $\mathrm{N}=106,24.88 \%)$, knowledge of field education $(\mathrm{N}=61,14.32 \%)$, communication and cooperation $(\mathrm{N}=56,13.15 \%)$, field knowledge $(\mathrm{N}=55$, $12.91 \%)$, management of teaching and learning processes $(\mathrm{N}=38,8.92 \%)$, personal and Professional development $(\mathrm{N}=34,7.98 \%)$, creating learning environments $(\mathrm{N}=23,5.40 \%)$, universal values $(\mathrm{N}=22,5.16 \%)$, education planning $(\mathrm{N}=21,4.93 \%)$, knowledge of regulations $(\mathrm{N}=8,1.88 \%)$, and assessment and evaluation ( $\mathrm{N}=2,0.47 \%)$. Thus, the importance level of these 11 sub-categories was given in Table 4.

Table 4. Ranking of Importance Levels of Sub-Categories of Cognitive Construct

\begin{tabular}{llll}
\hline Sub-categories & $\mathrm{N}$ & Mean & $\%$ \\
\hline Assessment and Evaluation & 2 & 6,50 & 0,47 \\
Knowledge of field education & 61 & 6,43 & 14,32 \\
Personal and Professional development & 34 & 6,21 & 7,98 \\
Communication and cooperation & 56 & 6,11 & 13,15 \\
The relationship with students & 106 & 5,75 & 24,88 \\
Knowledge of regulations & 8 & 5,50 & 1,88 \\
Field knowledge & 55 & 5,22 & 12,91 \\
Management of the teaching and learning & 38 & 4,77 & 8,92 \\
process & 21 & 4,65 & 4,93 \\
Education planning & 23 & 4,56 & 5,40 \\
Creating learning environments & 22 & 3,83 & 5,16 \\
Universal values & & & \\
\hline
\end{tabular}


Table 4 shows that 11 sub-categories based on the importance level are as follows: assessment and evaluation ( $\mathrm{M}=6.5,0.47 \%)$, knowledge of field education ( $\mathrm{M}=6.43,14.3 \%)$, personal and Professional development $(\mathrm{M}=6.21$, $7.98 \%)$, communication and cooperation $(\mathrm{M}=6.11,13.15 \%)$, the relationship with students ( $M=5.75,24.88 \%)$, knowledge of regulations ( $M=5.50,1.88 \%)$, field knowledge $(\mathrm{M}=5.22,12.91 \%)$, management of the teaching and learning process $(M=4.77,8.92 \%)$, education planning ( $M=4.65,4.93 \%)$, creating learning environments $(M=4.56,5.40 \%)$, and universal values $(M=3.83$, $5.16 \%)$. Thus, these sub-categories were divided into three main categories, which were presented in Table 5.

Table 5. Main Categories of Cognitive Constructs

\begin{tabular}{|c|c|c|c|}
\hline Sub-categories & Main Categories & $\mathrm{N}$ & $\%$ \\
\hline $\begin{array}{l}\text { The relationship with students } \\
\text { Communication and cooperation } \\
\text { Personal and professional development } \\
\text { Universal values }\end{array}$ & Attitudes and values & 218 & 51,17 \\
\hline $\begin{array}{l}\text { Management of the teaching and learning } \\
\text { process } \\
\text { Education planning } \\
\text { Creating learning environments } \\
\text { Assessment and evaluation }\end{array}$ & Professional Knowledge & 124 & 29,11 \\
\hline $\begin{array}{l}\text { Knowledge of field education } \\
\text { Field knowledge } \\
\text { Knowledge of regulations }\end{array}$ & Professional Skill & 84 & 19,72 \\
\hline
\end{tabular}

Table 5 shows three main categories, which were as follows: attitudes and values $(\mathrm{N}=218,51.17 \%)$, professional knowledge $(\mathrm{N}=124,29.11 \%)$, and professional skill $(\mathrm{N}=84,19.72 \%)$. Thus, the model of a good IT academician was presented in Figure 1. 


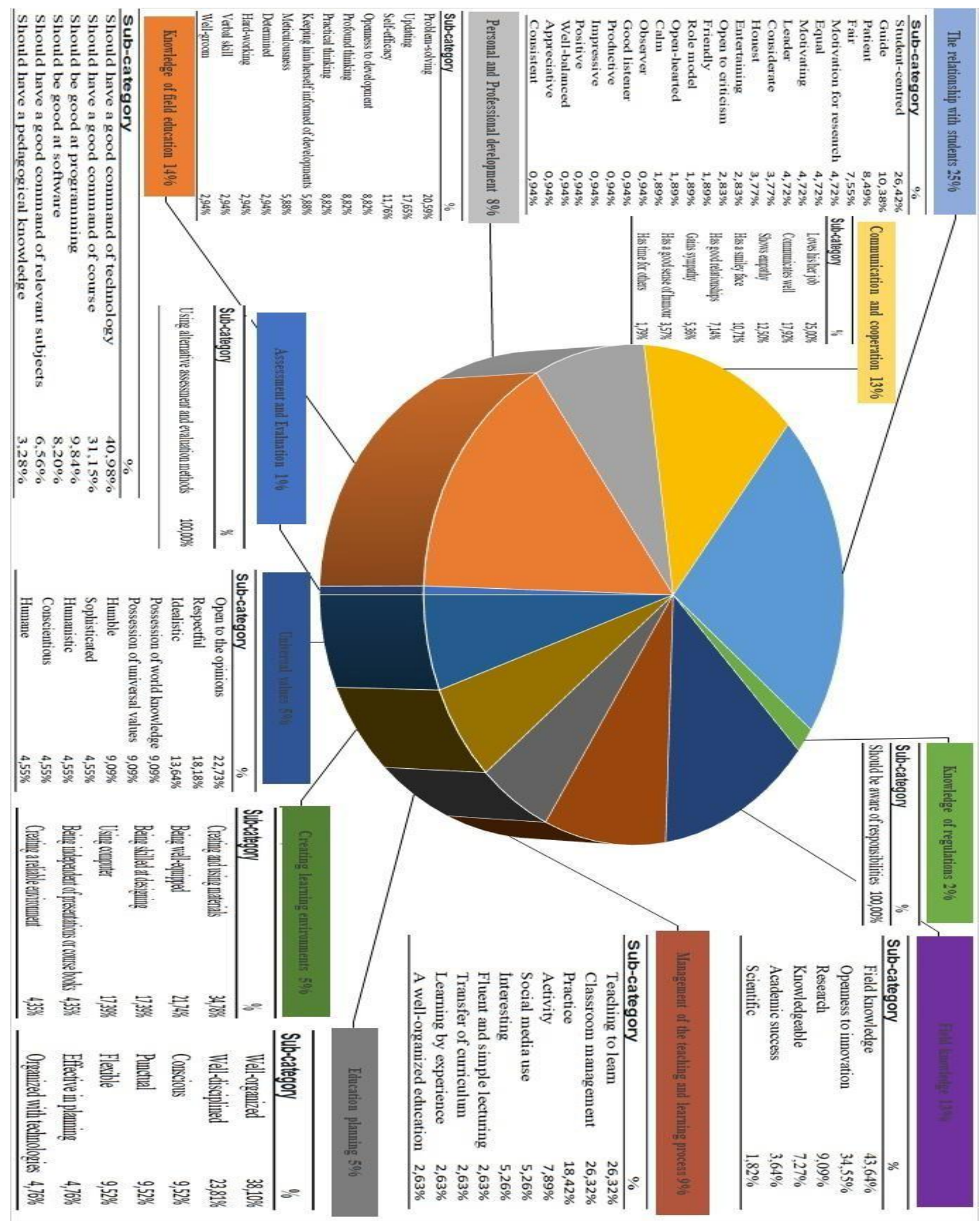


Figure 1 includes 11 sub-categories that were divided into internal constructs ranked in percentage. The three main characteristics of a good IT academician in the model were the relationship with students by $25 \%$, knowledge of field education by $14 \%$, and field knowledge by $13 \%$. The essential constructs of the relationship with students were studentcenteredness by $26.42 \%$ and guidance by $10.38 \%$. The essential constructs of field knowledge were good command of technology by $40.98 \%$ and a good command of a specific course by $31.15 \%$. Finally, the essential constructs of knowledge of field education were field knowledge by $43.64 \%$ and openness to innovation by $34.55 \%$.

\section{Discussion}

This study was designed to reveal and model the cognitive constructs of pre-service IT teachers regarding the characteristics of IT academicians using the exploratory sequential design and via the repertory grid form technique. However, since 9 repertory grid forms filled by pre-service IT teachers did not match the purpose of the research, they were excluded from the analysis. 426 cognitive constructs were produced by pre-service IT teachers regarding the characteristics of good IT academicians.

In the study, the top ten frequently repeated characteristics of IT academicians were found to be student-centeredness, good command of technology, field knowledge, good command of a specific course, good communication, openness to innovation, loving job, guidance, learning to teach, and classroom management. These results are similar to the results of some other studies, albeit in a different order. Sezer (2016) revealed similar cognitive constructs. Sezer (2018) found the following constructs: communication skills, professional competence, field expertise, motivation skills, geniality, fair behavior, respect for opinions, creativity, innovativeness, academic competence, being scientific, and classroom management. Başaran and Baysal (2016) also enumerated 10 cognitive constructs, which are as follows: conscience, patience, personal care, cleanness, amiableness, friendliness, decency, solution-orientation, fairness, and confidence. Furthermore, it should be noted that results are in line with the results of different studies in the literature (Senemoğlu, 2001; Stronge, Tucker \& Hindman, 2004; Telli, Brok \& Çağıroğlu, 2008; Gençtürk, Akbaş \& Kaymakc1, 2012; Küçükoğlu, Taşgın \& Saadni, 2014).

The cognitive constructs obtained in the study were collected in 11 sub-categories based on their similarity and common features. These categories were divided into three main categories, which were attitudes and values, professional knowledge, and professional skills, respectively. The importance levels of the categories collected were assessment and evaluation $(0.47 \%)$, knowledge of field education (14.3\%), personal and professional development (7.98\%), communication and cooperation (13.15\%), the relationship with students $(24.88 \%)$, knowledge of regulations $(1.88 \%)$, field knowledge $(12.91 \%)$, management of the teaching and learning process $(8.92 \%)$, education planning $(4.93 \%)$, creating learning environments 
(5.40\%), and universal values (5.16\%). Sezer (2016) obtained eight similar main categories considering the similarity and functionality. Başaran and Baysal (2016) examined the characteristics of good teachers in terms of the definition of a good teacher, individual characteristics, field competence, pedagogical formation, communication skills, general culture, the relationship with students, selection features, and educational environment. Therefore, this shows similarity with the findings of some studies (Beyer, 2002; Murphy, Delli, \& Edwards, 2004; Darling-Hammond \& BaratzSnowden, 2005) conducted in the literature.

Subsequently, the three main characteristics of good IT academicians were found to be the relationship with students, knowledge of education regarding the field, and knowledge of the field itself in the study. One may notice that the essential constructs regarding the relationship with students are student-centeredness and guidance. Besides, while the essential constructs of knowledge of field education are a good command of technology and course, the essential constructs of field knowledge are field knowledge and openness to innovation. Işıtaş (2015) emphasized the importance of using technology and pursuing innovation regarding the characteristics of a good teacher. These constructs overlap with the findings of studies conducted by (Yanpar-Yelken, Çelikkaleli \& Çapri (2007), Darling-Hammond (2008), Şahin (2011), Gençtürk, Akbaş \& Kaymakc1 (2012), Ulusoy (2013), Çalışkan, Işık \& Saygın (2013), Shuls \& Trivitt (2015)).

\section{Conclusion}

In conclusion, the good IT academician model that emerged in the study was comprised of 426 cognitive constructs collected under 11 subcategories of three main categories. Among the three main characteristics that constituted $52 \%$ of all, which the researcher believes are vital for the definition of a good IT academician, were the relationship with students by $25 \%$, knowledge of field education by $14 \%$, and field knowledge by $13 \%$. However, the model reveals a whole set of characteristics of a good IT academician rather than a few characteristics specified above. Therefore, the model taken as a whole may help explore the relationship between the characteristics of a good IT academician and evaluate them.

As today's world is evolving into a digital world, it is essential to keep up the advances, particularly in the field of IT and thus, those who are responsible for teaching in such fields should be well-educated. The findings of this study reveal that good IT academicians should possess the qualifications not only in the field but also in terms of pedagogical issues. For, students constitute the main parts of education life at all levels of education, therefore, academicians should be aware of strategies that may enhance student motivation and improve their relationships with students not only in classes but also outside of classes. This is a sort of prerequisite for good academicians. Besides, academicians should be well-equipped in terms of advances in the field without being confined to old methods and strategies 
to be applied while teaching. Finally, as field knowledge changes day by day, just like in any other professions or academicians in universities, IT academicians also should build on their field knowledge through reviews of articles, laboratory studies, policies, or methods created by other scholars in the field.

This study is limited to only the students of computer education and instructional technology teaching departments at three universities in Turkey. Thus, it should be kept in mind that more research is needed for the field and to contribute to the literature to reveal other characteristics of good academicians not only in the field of IT but also in other fields that are closely or slightly related to the field of IT.

\section{Implications and Recommendations}

The findings highlight that IT academicians should be provided with in-service training about student-centeredness and guidance as well as courses about using technology and innovative approaches. As this study was limited to 42 pre-service IT teachers, it is recommended that studies on more participants should be conducted. Finally, it is recommended that studies on the cognitive constructs of different phenomena may be carried out using similar techniques. 


\section{References}

1. Adams-Webber, J. R. (1996). Repertory grid technique. In R. Corsini \& A. J. Auerbach (Eds.), Encyclopaedia of Psychology (pp.782-783). New York: John Wiley \& Sons.

2. Akgün, M. (2016). How ought an ideal academic member in higher education to be?. Uludağ University Faculty of Arts and Sciences Journal of Philosophy, 26, 197-204. Retrieved from: https://doi.org/10.20981/kuufefd.97116

3. Akolaş, A. D. (2009). Teknoloji yönetimi ve teknoloji yönetim Süreci. Journal of ASUFEAS, 1(2), 203-218. Retrieved from: https://dergipark.org.tr/tr/pub/aksarayiibd/issue/22557/241016

4. Başaran, E. (1993). Eğitim psikolojisi, modern eğitimin psikolojik temelleri. Kadığlu Matbaası, Ankara, Turkey.

5. Beyer, L. (2002). The politics of standards and the education of teachers. Teaching Education, 13(3), 305- 316. Retrieved from: https://doi.org/10.1080/1047621022000023280

6. Creswell, J. W. (2003). Research design: qualitative, quantitative, and mixed methods approaches (2nd ed.). Thousand Oaks, CA: Sage.

7. Cüceloğlu, D. (1991). Insan ve davranışı. İstanbul: Remzi Kitabevi.

8. Çalışkan, M., Işık, A. N., \& Saygın, Y. (2013). Prospective teachers' perception of ideal teacher. Elementary Education Online, 12(2), 575584. Retrieved from: http://ilkogretimonline.org.tr/index.php/io/article/view/1421

9. Darling-Hammond, L. (2008). The case for university-based teacher education. In M. Cochran-Smith, S. Feiman-Nemser, D. J. McIntyre, \& K. E. Demers (Eds.), Handbook of research on teacher education: Enduring questions in changing contexts (pp. 333-346). NY: Routledge, Taylor \& Francis.

10. Darling-Hammond, L., \& Baratz-Snowden, J. (Eds.). (2005). A good teacher in every classroom: Preparing the highly qualified teachers our children deserve, pp. 38-39. San Francisco, CA: Jossey-Bass.

11. Davidson, D. (1977). The effect of individual differences of cognitive style on judgments of document relevance. Journal of the American Society for Information Science, 28, 273-84. Retrieved from: https://doi.org/10.1002/asi.4630280507

12. Demirel, Ö., \& Dinçer, S. (2017). Eğitim bilimleri yenilikler ve nitelik arayişi (Ankara, pegem akademi). 3. Bölüm Başaran A. R., \& Baysal S. (2016). Öğretmen adaylarının ideal bir ögretmen hakkındaki görüşleri, pp.29-44. Retrieved from: http://dx.doi.org/10.14527/9786053183563.003

13. Gallavan, N. P., Peace, T. M., \& Thomason, R. M. R. (2009). Examining teacher candidates' perceptions of teachers' professional dispositions. In P. R. LeBlanc \& N. P. Gallavan (Eds.), Affective teacher education: Exploring connections among knowledge, skills, and dispositions (pp.3960). NY: Rowman \& Littlefield Education. 
14. Gençtürk, E., Akbaş, Y., \& Kaymakcı, S. (2012). Qualifications of an ideal teacher according to social studies preservice teachers. Educational Sciences: Theory \& Practice, 12(2), 1569-1572. Retrieved from: https://www.researchgate.net/publication/295125497_Qualifications_of_a n_Ideal_Teacher_according_to_Social_Studies_Preservice_Teachers

15. Gordon, C. (1968). Self-conceptions: Configuration of content. in Burns R.B. (1979). The Self Concept, Harlow: Longman.

16. Işıktaş, S. (2015). Teachers candidates' views on good teacher. Hacettepe University Journal of Education. 30(4), 119-131. Retrieved from: https://www.researchgate.net/publication/288407481_Teacher_Candidate s'_Views_on_Being_a_Good_Teacher

17. Karacaoğlu, Ö.M. (2008). The perceptions of teachers' sufficiency. Yüzüncü Yll Üniversitesi Ë̆itim Fakültesi Dergisi, 5(1), 70-97. Retrieved from: http://efdergi.yyu.edu.tr/uploads/25_c_karacaoglu-1542112493.pdf

18. Kelly, G. A. (1955). The psychology of personal constructs. NY: Norton \& Company.

19. Kelly, G. A. (1991). The psychology of personal constructs theory and personality. London: Routledge.

20. Kelly, G. A. (2003). The psychology of personal constructs. London: Taylor \& Francis.

21. Khan, I. A. (2011). The Teacher of English: Pedagogic Relevance in Saudi Arabia. English Language Teaching, 4(2), 112-120. Retrieved from: https://eric.ed.gov/?id=EJ1080732

22. Kivinen, O., \& Rinne, R. (1995). Education of the elemantary-scholl teachers and the imagesof citizenship in Finland during 19th and 20th Centuries. Scandinavian Journal of Educational Research, 39(3), 237256. Retrieved from: https://doi.org/10.1080/0031383950390305

23. Küçükoğlu, A., Taşgın, A., \& Saadnie, A. (2014). A comparative research upon views of turkish and iranian teacher candidates about teaching profession. Atatürk Üniversitesi Türkiyat Araştırmaları Enstitüsü Dergisi, 51, 395-416. Retrieved from: https://dergipark.org.tr/tr/pub/ataunitaed/issue/2890/40103

24. Minor, L. C., Onwuegbuzie, A. J., Witcher, A. E., \& James, T. L. (2002). Preservice teachers' educational beliefs and their perceptions of characteristics of effective teachers. The Journal of Educational Research, 96(2), 116-127. Retrieved from: https://doi.org/10.1080/00220670209598798

25. Murphy, P. K., Delli, L. A. M., \& Edwards, M. N. (2004). The good teacher and good teaching: Comparing beliefs of second-grade students, preservice teachers and in-service teachers. The Journal of Experimental Education, 72(2), 69-92. Retrieved from: https://doi.org/10.3200/JEXE.72.2.69-92

26. Özdemir, M., \& Pınar, N. (2019). Globalization and developments in information and communication technologies. The Journal of International Social Research, 12 (64), Issn: 1307-9581. Retrieved from: http://dx.doi.org/10.17719/jisr.2019.3400 
27. Özgenel, M., Baydar, F., \& Çalışkan Yılmaz, F. (2018). Investigating the relation betwen secondary school students' attitudes towards information technology and software class and their academic achievement. Turkish studies, Information Technologies \& Applied Sciences, 13(6), 111-128. Retrieved from: http://dx.doi.org/10.7827/TurkishStudies.12962

28. Senemoğlu, N. (2001). Öğrenci görüşlerine göre öğretmen yeterlilikleri. Eğitimde Yansımalar: VI. (11-13 Ocak). Ankara: Öğretmen Hüseyin Hüsnü Tekışık Eğitim Araştırma Geliştirme Vakfı Yayınları, 193-215.

29. Sezer, Ş. (2016). School administrator's cognitive constructs related to ideal teacher qualifications: a phenomenological analysis based on repertory grid technique. Education and Science, 41(186), 37-51. Retrieved from: http://dx.doi.org/10.15390/EB.2016.6173

30. Sezer, S. (2018). Prospective teachers' cognitive constructs related to ideal lecturer qualifications: a case study based on repertory grid technique. Mediterranean Journal of Educational Research, 12(25), 255-273. Retrieved from: https://doi.org/10.29329/mjer.2018.153.14

31. Shuls, J. V., \& Trivitt, J. R. (2015). Teacher qualifications and productivity in secondary schools. Journal of School Choice, 9(1), 49-70. Retrieved from: https://doi.org/10.1080/15582159.2015.998964

32. Stronge, J. H., Tucker, P. D., \& Hindman, J. L. (2004). Handbook for qualities of effective teachers. Virginia: ASCD Publications.

33. Telli, S., Den Brok, P., \& Çakıroğlu, J. (2008). Teachers' and students' perceptions of the ideal teacher. Education and Science, 33(149), 118129. Retrieved from: http://egitimvebilim.ted.org.tr/index.php/EB/article/view/645/117

34. Ulusoy, M. (2013). Classroom teacher candidates' evaluations about ideal teacher and their own competencies. Uşak Üniversitesi Sosyal Bilimler Dergisi, 6(4), 324-341. Retrieved from: https://dergipark.org.tr/tr/pub/usaksosbil/issue/21640/232606

35. Witcher, A., \& Onwuegbuzie, A. J. (1999). Characteristics of effective teachers: Perceptions of preservice teachers. Paper presented at the annual meeting of the Mid-South Educational Research Association, Point Clear, AL. (ERIC Document Reproduction Service No. ED438246). Retrieved from: https://eric.ed.gov/?id=ED438246

Yanpar-Yelken, T., Çelikkaleli, Ö., \& Çapri, B. (2007). Eğitim fakültesi kalite standartlarının belirlenmesine yönelik öğretmen adayı görüşleri (Mersin Üniversitesi örneği). Mersin University Journal of the Faculty of Education, 3(2), 191-215. Retrieved from: https://dergipark.org.tr/tr/pub/mersinefd/issue/17387/181720 